\title{
$\begin{array}{lllllllllllllllllllll}\text { R } & \text { E } & \text { C } & \text { E } & \text { N } & Z & \text { J } & \text { E } & \text { I } & \text { S } & \text { P } & \text { R } & \text { A } & \text { W } & \text { O } & \text { Z } & \text { D } & \text { A } & \text { N } & \text { I } & \text { A }\end{array}$
}

Ius Matrimoniale

28 (2017) nr 4

DOI:10.21697/im.2017.28.4.07

\section{Christian Volkmar Witt, Martin Luthers Reformation der Ehe, Mohr Siebeck Verlag, Tübigen 2016, ss. 347}

W 2016 r. niemieckie Wydawnictwo „Mohr Siebeck” wydało interesującą monografię autorstwa Christiana Volkmara Witta „Martin Luthers Reformation der Ehe" poświęconą problematyce reformatorskiego postrzegania instytucji małżeństwa przez Marcina Lutra. W skład pozycji weszło sześć rozdziałów, będących następstwem logicznego wynikania i tworzących jedną kompozycyjną całość.

W rozdziale I „Martin Luthers erste umfassende Darlegung: sein Sermon «Vom ehelichen Leben»" Witt ukazał pierwszą wizję małżeństwa Lutra wyartykułowaną w „Mowie o życiu małżeńskim” (Vom ehelichen Leben). Dokonując szczegółowej analizy przemówienia wykazał on, iż zasadniczym fundamentem tej koncepcji były treści zawarte w Piśmie św. Według Reformatora, związek małżeński był instytucją powołaną wprawdzie przez Boga, ale pozbawioną charakteru sakramentalnego. W opinii Autora, w ujęciu tym istotne novum polegało przede wszystkim na położeniu szczególnego akcentu na kwestii zrodzenia potomstwa i wychowaniu go w związku małżeńskim. Luter utrzymywał bowiem, iż obowiązek jego wychowania spoczywa nie tyle na hierarchicznym Kościele, ile na środowisku rodzinnym.

Negatywnie odniósł się on także do sprawy czystości i dziewictwa, uznając je za przeciwne woli Bożej oraz ludzkiej naturze. Uważał, iż realizacja życiowego powołania wyraża się w zrodzeniu potomstwa, które uznał za główny cel małżeństwa. Ponadto stał on na stanowisku, iż Kościół nie jest uprawniony do wprowadzania przeszkód małżeńskich. Twierdził, iż wydawane w owym czasie dyspensy od 
tych prawnych ograniczeń służyły niczemu innemu, jak bogaceniu się Rzymu i korupcji.

Zdaniem Witta, taka wizja niosła za sobą dalsze następstwa. Reformator bowiem opowiadał się za rozwiązalnością węzła małżeńskiego; nie wykluczał możliwości zawierania powtórnych związków małżeńskich, dopuszczając taką ewentualność, ale pod pewnymi warunkami: po pierwsze, z przyczyny naturalnej jaką była śmierć współmałżonka, po drugie, wskazywał na rację, określoną jako „Selbsetzug”, dotyczącą sytuacji w której żona powstrzymywała się od współżycia seksualnego z mężem.

W rozdziale II zatytułowanym „Das theologische Eheverständnis Augustins" Autor monografii skupił uwagę na procesie recepcji przez Lutra doktryny św. Augustyna. Badając materiał źródłowy jakim były pisma tych wybitnych w dziejach chrześcijaństwa postaci zwrócił on uwagę, iż Reformator w konstrukcji swej wizji małżeństwa bazował na myśli biskupa Hippony. Dowiódł on, iż postrzeganie małżeństwa przez Lutra w znacznej mierze różniło się od augustynowego postrzegania małżeństwa. Według Witta, odmienność poglądów Reformatora wynikała przede wszystkim z jego nauki o usprawiedliwieniu. Rozwijając ten wątek wykazał on, iż w spuściźnie ojca Reformacji występuje brak całościowych rozważań na temat teorii dóbr, wypracowanej przez bpa Hippony. Lutra interesował szczególnie jeden aspekt, jakim było zrodzenie potomstwa i jego wychowanie. W opinii Witta, postulat ten wynikał z uprzedniej doktrynalnej przesłanki, iż rodzicie powinni być pierwszymi głosicielami Ewangelii.

W rozdziale III „Die mittelaterliche Reception der Ehetheologie Augustins durch Kirchenrecht und Sentenzenkommentare bis hin zum Bildungshorizont des Spätmittelalters" Autor przedstawił problem recepcji augustyńskiej teologii małżeństwa w średniowiecznym prawie kościelnym oraz Komentarzach do Sentencji. Rozważając ten problem najpierw w zarysie zaprezentował on prawny koncept małżeństwa występujący w „Corpus Iuris Canonici”. Dla kanonisty ta część monografii wydaje się mało interesująca ze względu na fakt, iż zawarte w niej treści można znaleźć w wielu opracowaniach z historii prawa kościelnego. W lekturze tej pozycji trzeba być jednak świadomym tego, iż cel eksploracji badawczej w pozycji tej jest 
zupełnie inny. Głównym bowiem zamierzeniem, jak już zaznaczono, jest przedstawienie reformatorskiej wizji małżeństwa Lutra; bardziej szczegółowo wskazanie na racje odmiennego od dotychczasowej chrześcijańskiej Tradycji postrzegania małżeństwa. Dlatego uważam, iż z aspektu metodologicznego podjęcie tego wątku trzeba uznać za konieczne, ponieważ wprowadza on czytelnika w rozważania zasadnicze prowadzone w dalszej części rozdziału, stanowiąc z jednej strony ich kontekst, z drugiej zaś podstawową bazę do dalszych analiz.

Moim zdaniem, tym co jest szczególnie godne uwagi w tym Rozdziale, to analizy poświęcone współzależności zachodzącej pomiędzy doktryną św. Augustyna, „Corpus Iuris Canonici”, a doktryną wielkiego Reformatora. Z punktu naukowego za niezwykle cenny uznaję wywód dotyczący odmienności myśli Lutra w odniesieniu do średniowiecznej kanonistycznej wizji małżeństwa. Badając materiał źródłowy Witt dowiódł, iż Luter w pierwszym rzędzie negował wprowadzenie w prawie kanonicznym instytucji przeszkód małżeńskich. Oponując przeciw tym prawnym ograniczeniom wskazywał on na brak biblijnych podstaw co do podejmowania takich decyzji przez prawodawców kościelnych, a także na ich korupcjogenny charakter w ówczesnym Kościele, związany z udzielaniem dyspens.

Ponadto, Reformator w swym ujęciu koncepcyjnym sprowadził liczbę dóbr do dwóch, jakimi były „proles” i „fides”. Odrzucał również pojmowanie czystości w „Corpus Iuris Canonici” w kategoriach „corona ab institutione Romane ecclesiae in signo regni habentes”. Według Witta, tym sposobem znacznie przyczynił się on do nowej formacji życia chrześcijańskiego w kulturze światowej.

Kolejnym obiektem badań Autora stały się treści zawarte w takich innych średniowiecznych pozycjach, jak: „Sentencje” Piotra Lombarda i „Komentarze” sporządzone do nich przez św. Bonawenturę, Ryszarda de Mediavilla, Tomasza ze Strasburga, a także dzieła Johanna Altestingsa „Vocabolarium Theologie” oraz „Summa Angelica”, autorstwa Angelusa z Clavassio. Dowiódł on, iż Luter przeciwstawił się małżeńskiej teologicznej doktrynie funkcjonującej w XV w.

W Rozdziale III zatytułowanym „Zäsur durch Verknüpfung: Luters theologisches Eheverständnis bis 1522 vor dem Hintegrund des 
ehetheologischen Bildungshorizont des Spätmittelaters” Witt podjął dalszy namysł nad spuścizną Lutra w okresie do 1522 r. Badając wpływ późnośredniowiecznej teologii na koncept małżeństwa występujący w takich jego dziełach, jak „De captivitate Babilonica” i „Sermon von dem Elichen Stand” pokazał on, iż Reformator prawniczą wiedzę w kwestii przeszkód małżeńskich czerpał głównie z „Summa Angelica”. Analizując treści zawarte w wymienionych przed chwilą pozycjach dowiódł on, iż Luter negował sakramentalność małżeństwa $\mathrm{z}$ tego powodu, że był przekonany, iż katolicka doktryna w tej kwestii nie znajdowała umocowania w Piśmie św. Nawiązując do Ef 5, odrzucił on też doktrynalne pojmowanie małżeństwa w kategoriach związku Chrystusa ze swoim Kościołem.

Ponadto Autor monografii wykazał, iż Luter sprzeciwiając się praktyce składania ślubów zakonnych zanegował średniowieczną doktrynę dotyczącą grzechu i łaski. Stał bowiem na stanowisku, że antropologicznie, życie w czystości przekracza możliwości grzesznego człowieka. Prawo duchownych do założenia rodziny Reformator wywiódł z 1 Tm 3, 2 i Tt 1, 6. Uzasadniając to twierdzenie posłużył się on następującym rozumowaniem: zasadnicze źródło pochodzenia małżeństwa tkwi w Bogu, Bóg natomiast stoi ponad papieżem.

Ze źródłowych badań przeprowadzonych w tym Rozdziale wynika, iż wizja małżeństwa Reformatora była inspirowana nauką św. Augustyna, treściami zawartymi w „Corpus Iuris Canonici”, średniowiecznymi Księgami Sentencji i późnośredniowieczną literaturą. Nie oznaczało to jednak, iż stworzony koncept polegał na kompilatorskim przejęciu zawartych w nich ujęć; wręcz odwrotnie był on jak na owe czasy na wskroś nowatorski.

$\mathrm{W}$ rozdziale $\mathrm{V}$ „Profilierung durch Vertiefung: Luters theologische Eheverständnis seit 1522" przedmiotem uwagi Autora stały się dalsze materiały źródłowe, pochodzące z 1522 r. i lat następnych. Badając takie pozycje jak „Ursach und Antwort da $\beta$ Junfrauen Klöster göttlich verlassen mögen”, „Das siebente Kapitel S. Pauli zu den Corinthen”, „Das Eltern die Kinder zur Ehe nicht Zwinger noch hindern und die Kinder ohne Eltern Willen sich nich verloben sollen”, „Der 127. Pslam ausgelegt an die Christen zu Riga in Lieslant”, „Traubüchlein für einfältigen 
Pfarrherr”, „Prädigten über das ente Buch Mose”, „Prädigt über Ehestand”, „Von Ehesachen”, „Vermahnung an die Geistlichen” i „Hochzeitpredigt über den Spruch Hebr. 13, 4" wykazał on, iż postrzeganie małżeństwa przez Lutra w przedziale czasowym, określonym w tytule rozdziału, zostało pogłębione i oparte na nauce o usprawiedliwieniu.

Wreszcie w Rozdziale VI „Abschließende Bündelung: Luhers große Genesisvorlsessung als letztes Dokument des eheteologisches Bruchs mit den Vorgaben Augustins”, posiadającym charakter konkludujący, Witt udowodnił, iż na reformatorską koncepcję małżeństwa Lutra decydujący wpływ wywarła egzegeza tekstów Księgi Rodzaju, inspirowana nieco odmiennym od dotychczasowego postrzegania chrześcijaństwa.

Konkludując przedstawioną pozycję, bardzo trudną w lekturze, pod względem merytorycznym oceniam bardzo wysoko. Zaprezentowane przez Ch. V. Witta analizy oparte głównie na materiale źródłowym i na solidnej literaturze posiadają charakter dogłębny. Pragnę podkreślić, iż Autor nie tylko przytacza teksty źródłowe i opisuje je, ale przede wszystkim bada je. Nie dotyczy to tylko spuścizny Marcina Lutra, lecz także innych materiałów źródłowych związanych z poruszanymi przez Witta zagadnieniami. Uważam, iż tym co jest niezwykle cenne $z$ naukowego punktu widzenia to nie tylko ukazywana problematyka, ale przede wszystkim wnioski badawcze jakie sformułował Autor monografii.

Recenzując tę monografię pragnę też wskazać na specyficzną metodę pisania tej pozycji zastosowaną przez Autora. Otóż w Rozdziale I Witt dokonał szczegółowej analizy „Mowy o życiu małżeńskim” wyodrębniając poszczególne komponenty doktryny Lutra. $\mathrm{W}$ następnych rozdziałach (II-V), badając natomiast inny materiał źródłowy, określił ich wpływ na reformatorskie ujęcia koncepcyjne Ojca Reformacji. W Rozdziale VI ukazał on rezultaty swych badań.

W moim przekonaniu, pozycja, którą zrecenzowałem jest nie tylko godna uwagi $z$ aspektu poznawczego, ale przede wszystkim stanowi ona bardzo cenny wkład w rozwój badań nad instytucją małżeństwa w kulturze chrześcijańskiej. 